\title{
Prevalence of Organophosphorous Pesticide Residues in Pumpkin, Spinach and Sorrel Leaves Grown in Akwanga, Nasarawa State, Nigeria
}

\author{
E. G. Ibrahim¹, N. Yakubu'², L. Nnamonu' 3 , J. M. Yakubu ${ }^{4}$ \\ ${ }^{1}$ Dept. of Pure and Applied Chemistry, Plateau State University Bokkos, Jos, Plateau Stae, Nigeria \\ ${ }^{2}$ Demonstration Secondary School, College of Education, Akwanga, Nasarawa State, Nigeria \\ ${ }^{3}$ Dept. of Chemistry and Agrochemical Technology, University of Agriculture, Ma-kurdi, Benue State, Nigeria \\ ${ }^{4}$ Dept. of Microbiology, Federal University Wukari, Wukari, Nigeria \\ Email: ezekiel_ibrahim@yahoo.com
}

How to cite this paper: Ibrahim, E.G., Yakubu, N., Nnamonu, L. and Yakubu, J.M. (2018) Prevalence of Organophosphorous Pesticide Residues in Pumpkin, Spinach and Sorrel Leaves Grown in Akwanga, Nasarawa State, Nigeria. Journal of Environmental Protection, 9, 516-524.

https://doi.org/10.4236/jep.2018.95032

Received: March 27, 2018

Accepted: May 14, 2018

Published: May 17, 2018

Copyright $\odot 2018$ by authors and Scientific Research Publishing Inc. This work is licensed under the Creative Commons Attribution International License (CC BY 4.0).

http://creativecommons.org/licenses/by/4.0/

(c) (i) Open Access

\begin{abstract}
Three green leafy vegetable samples of pumpkin leaves, spinach leaves, and sorrel leaves were collected from three different locations in a farm in Akwanga and were tested for the presence of organophosphorus (OP) compounds. The concentrations of all the pesticide residues in the vegetable samples were determined using gas chromatography with mass spectrometry (GC-MS). The organophosphorus pesticides detected include carbaryl (0.052 $\mathrm{mg} / \mathrm{kg}$ ) in pumpkin, this is below European maximum residues limit (EU MRL) of $0.1 \mathrm{mg} / \mathrm{kg}$, Dimethoate was found in pumpkin $(0.165 \mathrm{mg} / \mathrm{kg})$, spinach $(0.103 \mathrm{mg} / \mathrm{kg})$ and sorrel $(0.250 \mathrm{mg} / \mathrm{kg})$ all above the EU MRL of 0.05 $\mathrm{mg} / \mathrm{kg}$. Dichlofenthion was detected in pumpkin $(0.308 \mathrm{mg} / \mathrm{kg})$, pirimiphos methyl was detected in pumpkin and spinach $(0.428 \mathrm{mg} / \mathrm{kg}$ and $0.149 \mathrm{mg} / \mathrm{kg}$ respectively), all these were below the EU MRL of $0.5 \mathrm{mg} / \mathrm{kg}$. Chlorpyrifos was found in spinach $(0.230 \mathrm{mg} / \mathrm{kg})$ and sorrel $(0.192 \mathrm{mg} / \mathrm{kg})$ only spinach was above the EU MRL of $0.2 \mathrm{mg} / \mathrm{kg}$. The pesticide residue Bromophosethyl was detected in all vegetables, pumpkin leaves $(0.501 \mathrm{mg} / \mathrm{kg})$, sorrel $(1.571 \mathrm{mg} / \mathrm{kg})$ and spinach $(7.981 \mathrm{mg} / \mathrm{kg})$ all above the EU MRL of $0.5 \mathrm{mg} / \mathrm{kg}$. The remaining pesticides detected were all below their EU MRL value; these are Ethion found in spinach $(0.167 \mathrm{mg} / \mathrm{kg})$, Methyl Parathion in spinach $(0.103 \mathrm{mg} / \mathrm{kg})$ and sorrel $(0.335 \mathrm{mg} / \mathrm{kg})$. The levels of some of the organophosphorus pesticide residues found in vegetables were above the maximum residue limits (MRLs) set by the European Union. This calls for laws to regulate the use and circulation of such chemicals. Based on the observation made in these studies,
\end{abstract}


it is proposed that more extensive monitoring investigation covering all vegetables part in Akwanga Nasarawa state be carried out to find the exact position of pesticide residues.

\section{Keywords}

Akwanga, Pesticide Residues, Organophosphorous, Maximum Residue Limit

\section{Introduction}

Organophosphate (OP) pesticides are a group of insecticides or nerve agent acting on the enzymes acetytyl cholinesterase. The term is used often to describe virtually all organic phosphorus containing compounds especially when dealing with neurotoxin compounds [1]. These insecticides are one of the most common classes of chemicals used for the control of insects on vegetables because of their high efficacy and broad spectrum of activity [2]. Organophosphorus residues are likely to occur in vegetables such as lettuce and cabbage. Because this organophosphorus is inappropriate and illegal use, this further increases the risk of human exposure, hence it is important to determine the levels of organophophorus residues in vegetable to protect human health [3] [4] [5] [6]. About 70\% of insecticides used in the United States are organophosphate. Organophosphate pesticides degrade rapidly by hydrolysis on exposure to sunlight, air and soil, although small amount can be detected in food and drinking water. Their ability to degrade made them alternative pesticides to organochlorines pesticides. Although the organophosphorus degrades faster than organochlorides, they have greater acute toxicity posing risks to peoples who may be exposed to large amount [7]. Organophosphate of primary concern includes Azinophos-methyl, Chlorophyrifos, diclorvos, DDVP dimethoate, ethphone, Malathion. They are biodegradable and have a shorter persistence compared to organochlorine pesticides; this makes them the most widely used pesticides in the U.S. [8]. They are widely sprayed over crops or soils, causing residues to be found in surface and ground water, fruits, vegetables and in drinking water [9]. Therefore, the aim of this research is to determine the organophosphorus pesticide residues in vegetables and its environmental effects in Akwanga, Nasarawa State Nigeria and recommend safe and best practices in its application for the farmers in this locality.

Fruits and vegetables are important components of the human diet after cereals. They are widely used for culinary purposes. They are of great importance in the diet because of their presence of vitamins and mineral salts and offer advantages over dietary supplement [10]. A generous intake of fruits and vegetables still prevent various types of diseases and keep a person energetic and active all through life [11]. Humans are usually exposed to pesticides through ingestion of contaminated fruits and vegetables treated with pesticides during planting seasons and certain residues of pesticides could be deposited after the harvest of 
crops. These three vegetables Pumpkin, Spinach and Sorrel are the mostly consumed vegetable in Akwanga and because of this, the studies will be focused on them. Pesticides are indispensable to the farmer in his fight against plant pest and diseases. Today, it is estimated that as much as $45 \%$ of the world's crop is destroyed by plant pests and diseases [12]. Thus in order to meet the demand of the world, it is essential to use the pesticides to protect the crops, both during growth and their subsequent storage and transport. However, the indiscriminate and injudicious uses of pesticides have resulted to widespread contamination in food and feed commodities [13]. The majority of the pesticide poisonings and deaths occur in the developing countries. This is due to the poor pesticide handling practices and use of more toxic pesticides by farmers of developing countries (like Nigeria). Farmers have enough understanding of acute pesticide poisoning but lack of awareness of the "chronic" effect of pesticide usage [14].

Pesticides are widely used in fruit and vegetables because of their susceptibility to insect and diseases attack. Consequently, food safety is a major public concern worldwide. During the last decades, the increasing demand of food safety has stimulated research regarding the risk associated with consumption of fruits and vegetables, as they constitute major part of human diet contributing nutrients and vitamins [15].

In general, food is the main exposure route because of food chain relationship that exists. Exposure to pesticide residues through the diet is assumed to be five orders of magnitude higher than other exposure routes, such as air and drinking water [16]. According to the World Health Organization [17], food consumption consists on average of $30 \%$ (by mass) of fruit and vegetables, and fruit and vegetables are the most frequently consumed raw or semi-processed, it is expected that they contain higher pesticides residue levels compared to either processed food groups of plant origins, such as bread and other foodstuffs based on cereal processing [18].

Given the potential risks of pesticides for public health, the use of pesticides in fruit and vegetable production is subjected to constant monitoring. About $10 \%$ $12 \%$ of total pesticides are used on fruits and vegetables crops. Their persistent use leads to build up of toxic residues on crop produce, which may exert adverse effect on human health in addition to disturbing the ecosystem. The problem is more serious in case of vegetables as these are often consumed either raw or without much processing or storage. Having global existence, organophosphorus insecticide residues have been re-ported from each and every environmental commodity such as water, vegetables, milk etc. [19].

\section{Methodology}

\subsection{The Study Area}

Akwanga is one out of the 13 local Government Area in Nasarawa State, Nigeria and the major occupation here is farming with a total population of 113,430 [20]. It has a land area of $996 \mathrm{~km}^{2}$ and it lies at latitude $8.9060 \mathrm{~N}$ and longitude 
8.40750E. It is a city that leads to the Federal Capital Abuja, and because of its proximity to the Federal Capital a lot of people from the federal capital come to buy food items from here. The study focus on organophosphorus because of shift in attention from organochlorine pesticides due to long term problem associated with it.

\subsection{Collection of Vegetable Samples}

At each sampling site, $20 \mathrm{~g}$ each of the three vegetables: pumpkin, spinach and sorrel were collected from three different locations in one farm to provide replicate samples of each crop. The vegetables samples were collected in to a clean polyethylene bag label and put in a cool box and transported to the laboratory stored in a refrigerator at $4^{\circ} \mathrm{C}$ pending extraction.

\subsection{Extraction of Vegetable Samples}

The method of extraction used for the vegetables was USEPA method 3510 for extracting pesticides residues in non fatty crops, using ethyl acetate as the solvent. Sodium hydrogen carbonate $\left(\mathrm{NaHCO}_{3}\right)$ was used to neutralize any acid that may be present and the vegetables samples were washed thoroughly with distilled water. Twenty grams $(20 \mathrm{~g})$ of each sample was placed in a mortar and anhydrous sodium sulphate $\left(\mathrm{Na}_{2} \mathrm{SO}_{4}\right)$ was used to remove water from the sample matrix. The weighed sample in a mortar was grounded to a paste using a pestle. The paste was transferred into a conical flask with the help of a spatula and 400 $\mathrm{mL}$ of ethyl acetate was added and shaken thoroughly. A $5 \mathrm{~g}$ portion of sodium hydrogen carbonate $\left(\mathrm{NaHCO}_{3}\right)$ was added to the mixture followed by $20 \mathrm{~g}$ of anhydrous sodium sulphate $\left(\mathrm{Na}_{2} \mathrm{SO}_{4}\right)$, the entire mixture was shaken vigorously for one hour. This process was to ensure that enough of the pesticide residues dissolved in the ethyl acetate. The procedure was repeated for the samples from each of the vegetables and the mixture was filtered into a labeled container before centrifuged at a speed of $1800 \mathrm{rpm}$ for 5 minutes. The organic layer was decanted into a container and 1:1 mixture of $5 \mathrm{~mL}$ ethyl acetate and cyclohexane was added [21].

\subsection{Clean up of Vegetable Extracts}

After centrifugation, the samples were cleaned up using dispersive solid-phase extraction (dSPE). One milliliter of the supernatant was transferred to a $15 \mathrm{ml}$ PTFE tube to which $50 \mathrm{mg}$ each of $\mathrm{C}_{18}$ and PSA (primary and secondary amine sorbents) with $150 \mathrm{mg} \mathrm{MgSO}_{4}$ was added and vortexed for 30seconds and then centrifuged for 1 minute at $1500 \mathrm{rpm}$. The clear extract was then transferred to an auto sampler vial for GC-MS analysis.

\subsection{Determination of Pesticide Residues}

The Shimadzu GCMS (GC - 17A) QP 2010 installed with a 35\% diphenyl, 65\% dimethylpolysiloxane column was used for the chromatographic separation. The 
oven was programmed as follows: initial temperature $40^{\circ} \mathrm{C}, 1.5$ minutes, to $150^{\circ} \mathrm{C}, 15$ minutes, $5^{\circ} \mathrm{C} /$ minute to $200^{\circ} \mathrm{C}, 7.5$ minutes, $25^{\circ} \mathrm{C} /$ minute to $290^{\circ} \mathrm{C}$ with a final hold time of 12 minutes and a constant column flow rate of 1 $\mathrm{ml} / \mathrm{minute}$. The detection of the organophosphorus pesticides was performed using the GC-MS. Detection of pesticides was performed using the GC-ion trap MS with optional MSn mode. The scanning mode offer enhances selectivity over either full scan or selected ion monitoring (SIM). At the elution time of each pesticide using selected ion monitoring, the ratio of the intensity of matrix ions increase exponentially versus that of the pesticide ions as the concentration of the pesticide approach the detection limit, decrease the accuracy at lower levels. The GC -ion trap MS was operated in MSn mode and perform tandem MS function by injecting ions into the ion trap and destabilizing matrix ions, isolating only the pesticide ions. The retention time, peak area and peak height of the sample were compared with those of the standards for quantification.

\subsection{Data Handling}

External calibration and recovery tests were performed. The residue results were the means from the three replicates of each treatment and all data were analyzed using simple descriptive statistics such as means, standard deviations, using Anova Table: SPSS V-20.

\section{Results and Discussion}

The results of prevalence of organophosphorus pesticides residues in pumpkin, spinach and sorrel leaves studied are shown in Table 1. Carbaryl was detected in pumpkin at a level range between 0.046 to $0.066 \mathrm{mg} / \mathrm{kg}$ with the average concentration of $0.052 \mathrm{mg} / \mathrm{kg}$ which is below the European Union maximum residual limit (EU MRL) of $0.1 \mathrm{mg} / \mathrm{kg}$ for edible vegetables. Carbaryl was not detected in spinach and sorrel leaves. Dmethoate was found in all samples. The average Dimethoate concentration in pumpkin is $0.165 \mathrm{mg} / \mathrm{kg}$, spinach is $0.103 \mathrm{mg} / \mathrm{kg}$ and sorrel is $0.25 \mathrm{mg} / \mathrm{kg}$, all these concentrations exceeded the EU MRL of 0.05 $\mathrm{mg} / \mathrm{kg}$. This indicates that consumption of these leafy vegetables over time could pose a risk to this community since these vegetables are majorly consumed in this area. The value of Dimethote in sorrel showed significant difference signifying a very high abundance in the sample (Figure 1). Diazinon was detected in Pumpkin at a concentration of $0.138 \mathrm{mg} / \mathrm{kg}$, spinach $0.249 \mathrm{mg} / \mathrm{kg}$, and sorrel $0.251 \mathrm{mg} / \mathrm{kg}$ they all exceeded the EU value of $0.02 \mathrm{mg} / \mathrm{kg}$, this could be as the results of constant use of the organophosphorus pesticides in farm by farmers within this area. Dichlofenthion was detected only in Pumpkin at a level of 0.308 $\mathrm{mg} / \mathrm{kg}$; pirimiphos methyl was detected in pumpkin $0.428 \mathrm{mg} / \mathrm{kg}$ and spinach $0.149 \mathrm{mg} / \mathrm{kg}$ which are all below the EU MRL concentration of $0.5 \mathrm{mg} / \mathrm{kg}$. Also chlorpyrifos which is another common pesticide was detected in only 2 samples spinach $0.230 \mathrm{mg} / \mathrm{kg}$ and sorrel $0.192 \mathrm{mg} / \mathrm{kg}$, only the concentration in spinach exceeded the EU MRL value of $0.2 \mathrm{mg} / \mathrm{kg}$ for chlorpyrifos. 


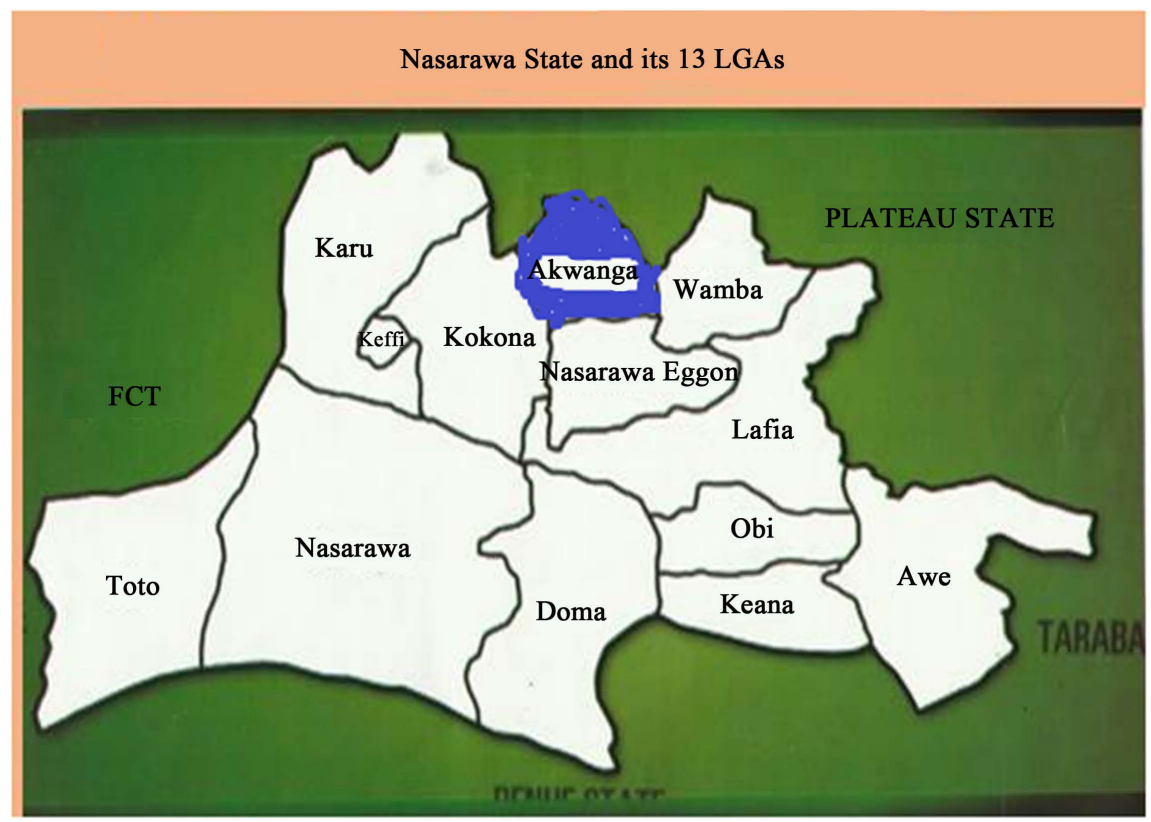

Figure 1. Map of Nasarawa state depicting the location of Akwanga.

Table 1. Mean concentration of organophosphorus pesticide residues in three green leafy vegetables. samples were analysed in triplicate, the range is displayed in brackets and BDL represents below detection limit.

\begin{tabular}{cccc}
\hline \multirow{2}{*}{ Pesticide } & \multicolumn{3}{c}{ Vegetable concentration $(\mathrm{mg} / \mathrm{kg})$} \\
\cline { 2 - 4 } & Pumpkin leaves & Spinach leaves & Sorrel leaves \\
\hline \multirow{2}{*}{ Carbaryl } & $0.052 \pm 0.01$ & $\mathrm{BDL}$ & $\mathrm{BDL}$ \\
& $(0.046-0.066)^{\mathrm{a}}$ & - & - \\
Dimethoate & $0.165 \pm 0.05$ & $0.103 \pm 0.02$ & $4.521 \pm 1.18$ \\
& $(0.131-0.198)$ & $(0.088-0.118)$ & $(3.310-5.676)$ \\
Diazinon & $0.138 \pm 0.04$ & $0.249 \pm 0.05$ & $0.251 \pm 0.07$ \\
& $(0.103-1.870)$ & $(0.214-0.239)$ & $(0.199-0.302)$ \\
Dichlofenthion & $0.308 \pm 0.13$ & $\mathrm{BDL}$ & $\mathrm{BDL}$ \\
& $(0.187-0.450)$ & - & - \\
Pirimiphosmethyl & $0.428 \pm 0.04$ & $0.149 \pm 0.0$ & $\mathrm{BDL}$ \\
Chlorpyrifos & $(0.397-0.459)$ & $(0.00-0.149)$ & - \\
& $\mathrm{BDL}$ & $0.2295 \pm 0.06$ & $0.197 \pm 0.10$ \\
Bromophosethyl & $0.501 \pm 0.68$ & $(0.109-0.274)$ & $(0.114-0.306)$ \\
& $(0.020-0.981)$ & $(5.871-10.092)$ & $\mathrm{BDL}$ \\
Ethion & $\mathrm{BDL}$ & $0.167 \pm 0.09$ & - \\
& - & $(0.101-0.233)$ & $\mathrm{BDL}$ \\
Methyl parathion & $\mathrm{BDL}$ & $0.103 \pm 0.0$ & - \\
& - & $(0.000-0.103)$ & $\mathrm{BDL}$ \\
\hline
\end{tabular}

Out of the organophosphorus pesticides studied, Bromophosethyl as shown in Figure 2 has the highest concentrations of $7.981 \mathrm{mg} / \mathrm{kg}$ in spinach leaves followed by $0.501 \mathrm{mg} / \mathrm{kg}$ in pumpkin leaves, however it was not detected in sorrel leaves. All these values showed significant difference which implies that their 


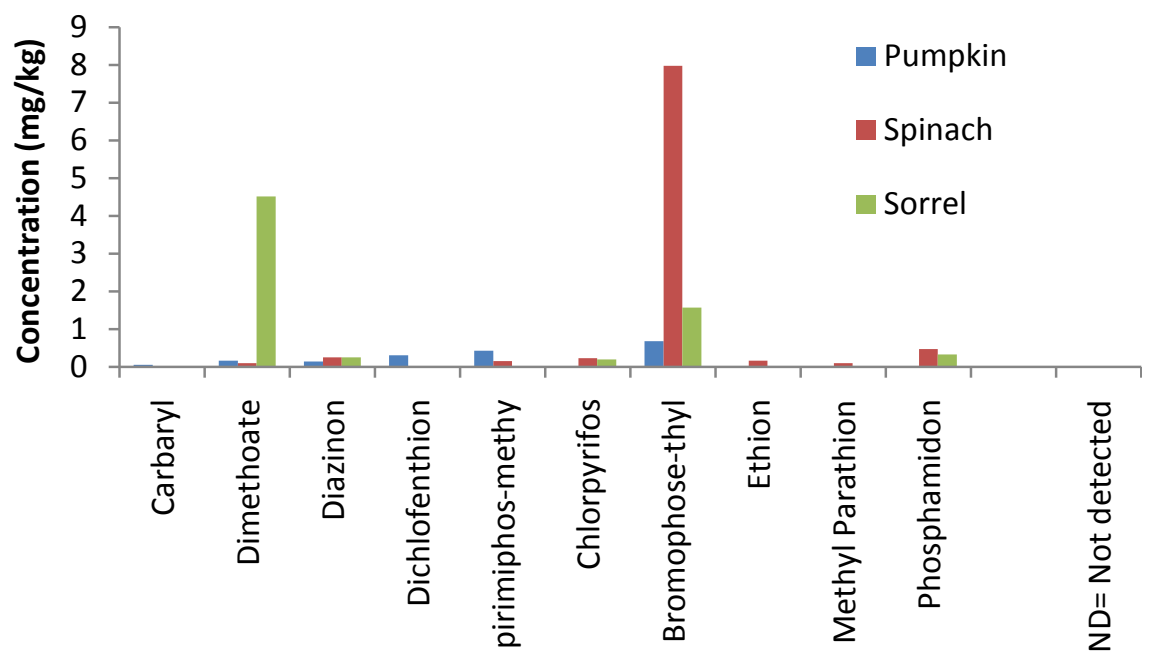

Figure 2. Mean concentrations of organophosphorus pesticide residues in three green leafy vegetable.

abundance is high or all the vegetables tend to have high rate of absorption of this pesticide.

The remaining three organophosphorus pesticide residues that were detected were all found in few samples and they were all below their respective EU MRL's set for vegetables. This included Ethion found in spinach $0.167 \mathrm{mg} / \mathrm{kg}$ (MRL-0.3), methyl parathion found only in spinach $0.103 \mathrm{mg} / \mathrm{kg}$ and sorrel $0.335 \mathrm{mg} / \mathrm{kg}$, all below the EU MRL value of $0.5 \mathrm{mg} / \mathrm{kg}$. The findings are in agreement with discoveries in Ghana by Bempah et al., (2011) [22] and Bhanti and Taneja (2007) [13]. The concentration of most of these were well below the established tolerances but continuous consumption of such vegetable even with moderate contamination level can accumulate in the receptors body and may prove dangerous to human population in the long term [13].

The cause of relatively low contamination may be attributed to change in the usage pattern of different groups of insecticides in Akwanga. In the past one decade, there has been shift in the use of pesticides which favor the use of organophosphorus instead of the earlier used of organochlorine which is more persist to environmental degradation. Mostly the shift has occurred in favor of the organophosphorus, carbamate and SP insecticides because of their wide spectrum of activity and less persistence [23].

\section{Conclusion}

This study which focused on the three major vegetable leaves consumed in this area, identified that the concentrations of Dimethoate in pumpkin, spinach and sorrel leaves were above the European Union maximum residual limit of 0.05 $\mathrm{mg} / \mathrm{kg}$. This standard was used because most of the developing countries including Nigeria have no set-up standard of their own, for this, they depend on the European Union standard or guiding limit for their justification. The study focuses on only leaves, there is need for further research to be carried out to as- 
certain these residues in other parts of the plants particularly stem, root and even the soil to be able to make logical conclusion about the toxicity of these herbicides used in the area. The result also suggests there is need for proper education of farmers in this area as regard to monitoring the dosage use to avoid accumulation overtime which can be dangerous to human who consumed these. We also suggest further work on the seasonal determination of these pesticides. With these discovered, some of the organophosphorus pesticides are higher than the set standard, this could pose hazard to the local consumers and hinder trade, which in turn affect the economy activities of the locality.

\section{References}

[1] Akpagu, F.C., Nnamani, E.V. and Eze Chuckwuebuka, G.I. (2015) Analysis of Organophosphate Pesticides Residue on Crops in Abakaliki, Ebonyi State. IOSR Journal of Applied Chemistry (IOSR-JAC), 8.

[2] Wang, J.-L., Xia, Q., Zhang, A.-P., Hu, X.Y. and Lin, C.M. (2012) Determination of Organophosphorus Pesticides in Vegetables by an Enzymes Inhibition Method Using a-Naphthyl ac-Etate Esterase Extracted from Wheat Flour. Journal of Zhejiang University Science B (Biomedicine \& Biotechnology).

[3] Darko, G. and Akoto, O. (2008) Dietary Intake of Organophosphorus Pesticides Residues through Vegetables from Kumasi Ghana. Food and Chemical Toxicology, 46, 3703-3706. https://doi.org/10.1016/j.fct.2008.09.049

[4] Desilva, H.J., Samarawickrema, N.A. and Wickremasinghe, A.R. (2006) Toxicity Due to Organophosphhorus Compounds, What about Chronic Exposure. Transactions of the Royal Society of Tropical Medicine and Hygiene, 100, 803-806. https://doi.org/10.1016/j.trstmh.2006.05.001

[5] Uygun, U., Ozkara, R., Ozbey, A. and Kolisel, H. (2007) Residue Levels of Malathion and Fenitrothion and Their Metabolites in Post Harvest Treated Barley during Storage and Malting. Food Chemistry, 100, 1165-1169. https://doi.org/10.1016/j.foodchem.2005.10.063

[6] Zhao, J.H. and Zhao, D.G. (2009) Transient Expression of Organophosphorus Hydrolase to Enhance the Degrading Activity of Tomato Fruit on Coumaphos. Journal of Zhejiang University Science B (Biomedicine \& Biotechnology), 10, 1165-1169.

[7] Akpagu, F.C., Nnamani, E. and Eze Chukwuebuka, G.I. (2015) Analysis of Organophosphate Pesticides Residue on Crops in Abakaliki, Ebonyi State. Journal of Applied Chemistry (IOSR), 8, 26-29.

[8] Chen, J., Duan, C. and Guan, Y. (2010) Sorptive Extraction Techniques in Sample Preparation for Organophosphorus Pesticides in Complex Matrices. Journal of Chromatography B, 878, 1210-1225. https://doi.org/10.1016/j.jchromb.2010.02.031

[9] Sapahin, H.A., Ahmad, M. and Bahruddin, S. (2015) Determination of Organophosphorus Pesticides Residue in Vegetables Using Solid Phase Micro-Extraction Coupled with Gas Chromatography-Flame Photometric Detectors. Arabian Journal of Chemistry, 2-9.

[10] Ibitomi, M., Oluwarotimi, C. and Mohammed, F. (2016) Determination of Pesticides Residues in Fruits and Vegetables in Kaduna Metropolis, Nigeria. International Journal of Environmental Science and Toxicology Research, 4, 185-189.

[11] Zahir, E., Naqvi, I.I. and Uddin, M.S. (2009) Market Basket Survey of Selected Metals in Fruits from Kara-Chi City (Pakistan). Journal of Basic and Applied Sciences, 
$5,47-52$.

[12] Yakubu, N. (2015) Prevalence of Organochlorines and Organophosphorus Pesticides in Vegetables Grown in Akwanga, Nasarawa State, Nigeria. M.Sc. Thesis, University of Agriculture Makurdi, Benue State.

[13] Bhanti, M. and Taneja, A. (2007) Contamination of Vegetables of Different Seasons with Organ Phosphorus Pesticides and Related Health Assessment in Northern India. Chemosphere, 69, 63-68. https://doi.org/10.1016/j.chemosphere.2007.04.071

[14] Bhanti, M. and Taneja, A. (2005) Monitoring of Organochlorine Pesticide Residues in Summer and Winter Vegetables from Agra, India-A Case Study. Environmental Monitoring and Assessment, 100, 341-346.

[15] Zawiyah, S., CheMan, Y.B., Nazimah, S.A.H., Chin, C.K., Tsukamoto, I., Hamanyza, A.H. and Norhainzan, I. (2007) Determination of Organochlorine and Pyrethroid Pesticides in Fruit and Vegetables using SAX/PSA Clean-Up Column. Food Chemistry, 102, 98-103. https://doi.org/10.1016/j.foodchem.2006.05.003

[16] WHO (2003) GEMS/Food Regional Diets (Regional per Capita Consumption of Raw and Semi-Processed Agricultural Commodities). http://www.who.int/foodsafety/pub-lications/chem/regional-diets/en/

[17] Juraske, R., Mutel, C., Stoessel F. and Hellweg, S. (2009) Life Cycle Human Toxicity Assessment of Pesticides: Comparing Fruit and Vegetable Diets in Switzerland and the United States. Chemosphere, 77, 939-945.

https://doi.org/10.1016/j.chemosphere.2009.08.006

[18] Claeys, W.L., Jean-Francois, S., Bragard, C., Maghuin-Rogister, G., Luc, P. and Sciffers, B. (2011) Exposure of Several Belgain Consumer Groups to Pesticide Residues through Fresh Fruit and Vegetable Consumption. Food Control, 22, 508-516. https://doi.org/10.1016/j.foodcont.2010.09.037

[19] Kumari, B., Kumar, R., Madan, V.K., Singh, R., Singh, J. and Kathpal, T.S. (2002) Magnitude of Pesticidal Contamination in Winter Vegetables from Hisar, Haryana. Environmental Monitoring and Assessment, 87, 311-318. https://doi.org/10.1023/A:1024869505573

[20] National Bureau of Statistics (2006) Nigeria National Population Commission (Census) Report 1.

[21] Akan, J.C., Lafiya, L., Mohammed, Z. and Abdulrahman, F.I. (2013) Organophosphorus Pesticides Residues in Vegetables and Soil Samples from Alam Dam and Gongulong Agricultural Area, Borno State, Nigeria. International Journal of Environmental Monitoring and Analysis, 1, 58-64. https://doi.org/10.11648/j.ijema.20130102.14

[22] Bempah, C.K., Donkor, A.K., Yeboah, P.O., Dubey, B. and Osei-Fosu, P. (2011) A Preliminary Assessment of Consumer's Exposure to Organochlorine Pesticides in Fruits and Vegetables and the Potential Health Risk in Accra Metropolis, Ghana. Food Chemistry, 128, 1058-1065. https://doi.org/10.1016/j.foodchem.2011.04.013

[23] Kumari, B., Kumar, R., Madan, V.K., Singh, R., Singh, J.J. and Kathpal, T.S. (2003) Magnitude of Pesticide Contamination in Winter Vegetables from Hissar, Haryana. Environmental Monitoring and Assessment, 87, 311-318.

https://doi.org/10.1023/A:1024869505573 